\title{
SINTESIS SURFAKTAN METIL ESTER SULFONAT DARI PALM OIL METHYL ESTER DAN NATRIUM METABISULFIT DENGAN PENAMBAHAN KATALIS KALSIUM OKSIDA
}

\author{
Nirwana, Irdoni, dan Jatikta Yuniharti \\ Jurusan Teknik Kimia Fakultas Teknik Universitas Riau \\ Email: nirwana.hamzah@yahoo.com
}

\begin{abstract}
The most widely used surfactant is an anionic surfactant which is synthesized from petroleum namely Linear Alkylbenzene sulphonate (LABS). Methyl Ester Sulfonate which is currently being developed. Surfactant can produced from palm oil methyl ester via sulfonation sulfonate. When in this research using sodium metabisulphite. The aims of this work is to synthesize Methyl Ester Sulfonate surfactant from Palm Oil Methyl Ester using Sodium Metabisulphite and a catalyst Calcium Oxide. The effects of time and the mole ratio are also investigated. Sulfonation process carried out in 4, 5, 6 hours with mole ratio of 1: $0,5,1: 1,1: 1,5$, temperature of $80^{\circ} \mathrm{C}$ and with stirring speed of $450 \mathrm{rpm}$. It haven been found that the surfactant produced has density of $\left(0.89490 \mathrm{~g} / \mathrm{cm}^{3}-0.89545 \mathrm{~g} / \mathrm{cm}^{3}\right)$, viscosity $(2.0323 \mathrm{cP}-2.1329 \mathrm{cP}), \mathrm{pH}(2,03-$ $2,48)$, surface tension $(32.60 \mathrm{mN} / \mathrm{m}-33.60 \mathrm{mN} / \mathrm{m})$, interfacial tension $(30.45 \mathrm{mN} / \mathrm{m}-30.94$ $\mathrm{mN} / \mathrm{m})$, and the stability emulsion $(59.17 \%-89,17 \%)$.
\end{abstract}

Keywords: methyl ester, methyl ester sulfonate, sulfonated, surfactant

\section{PENDAHULUAN}

Surfaktan (surface active agent) merupakan senyawa kimia yang bersifat aktif permukaan yang dapat menurunkan tegangan permukaan cairan. Menurut Hapsari ${ }^{[1]}$, surfaktan yang paling banyak digunakan adalah surfaktan anionik ( $66 \%)$. Surfaktan anionik memiliki karakteristik hidrofilik yang disebabkan adanya gugus ion sulfat atau sulfonat. Surfaktan metil ester sulfonat (MES) adalah surfaktan anionik yang saat ini sedang dikembangkan. Surfaktan ini dapat diproduksi menggunakan bahan baku metil ester dari minyak sawit. Surfaktan MES memiliki kelebihan yaitu ramah lingkungan (biodegradable), dan memiliki sifat detergensi yang baik ${ }^{[2]}$.

Potensi Indonesia sebagai produsen surfaktan yang disintesis dari minyak sawit sangat besar, mengingat produksi minyak sawit Indonesia yang mengalami peningkatan. Crude Palm Oil (CPO) merupakan bahan yang potensial sebagai bahan dasar pembuatan surfaktan MES karena Indonesia adalah produsen minyak sawit utama di dunia dengan jumlah produksi pada tahun 2014 mencapai 31,5 juta ton. Keunggulan CPO sebagai bahan baku surfaktan MES yaitu ramah lingkungan dan bersifat terbarukan. Selain itu CPO memiliki komposisi $\mathrm{C}_{16}$ dan $\mathrm{C}_{18}$ yang banyak, yaitu masing-masing sebanyak $42,63 \%$ dan 39,32\%. Surfaktan MES dari Metil ester $\mathrm{C}_{16-18}$ memiliki daya detergensi yang baik, sifat toleransi terhadap ion $\mathrm{Ca}$, dan aktivitas permukaan yang baik sekitar ( $90 \%)$ dibandingkan Linear Alkylbenzene Sulphonate (LABS) ${ }^{[3]}$.

Berdasrakan fakta-fakta tersebut CPO berpotensi sebagai bahan baku pembuatan surfaktan MES. Penggunaan CPO sebagai bahan baku surfaktan MES akan lebih menarik dengan menggunakan agen pensulfonasi yang murah seperti natrium bisulfit $\left(\mathrm{NaHSO}_{3}\right)$ dan natrium metabisulfit $\left(\mathrm{Na}_{2} \mathrm{~S}_{2} \mathrm{O}_{5}\right)$. Penggunaan agen pensulfonasi $\mathrm{NaHSO}_{3}$ dan metil ester dari CPO pada proses pembuatan surfaktan MES telah dilakukan oleh Hidayati ${ }^{[4]}$. Surfaktan MES yang dihasilkan memiliki nilai tegangan permukaan 33 dyne $/ \mathrm{cm}$. Sedangkan Penggunaan agen sulfonasi $\mathrm{Na}_{2} \mathrm{~S}_{2} \mathrm{O}_{5}$ telah dilakukan Helianty dan Zulfansyah (2011) 
dengan bahan baku metil ester palm stearin. Metil ester palm stearin dapat disulfonasi pada suhu $80^{\circ} \mathrm{C}$ namun belum menunjukkan karakterisasi dari surfaktan $\mathrm{MES}^{[5]}$.

Dari uraian diatas, maka penulis memandang perlu melakukan penelitian mengenai sintesis surfaktan MES dari bahan baku nabati yang sangat potensial di Indonesia yaitu Palm Oil Methyl Ester (POME) dengan menggunakan agen pensulfonasi yang ekonomis dan diharapkan produk yang dihasilkan memberikan karakterisasi surfaktan MES yang mendekati surfaktan MES referensi.

\section{METODOLOGI PENELITIAN}

\section{Bahan dan Alat}

Bahan yang digunakan dalam penelitian ini adalah POME. Bahan-bahan kimia yang digunakan antara lain natrium metabisulfit
$\left(\mathrm{Na}_{2} \mathrm{~S}_{2} \mathrm{O}_{5}\right)$, kalsium oksida $(\mathrm{CaO})$, xilen, dan aquadest. Sedangkan alat adalah reaktor leher empat, stirrer dan rotor, water bath, kondensor, tachometer, termometer $100^{\circ} \mathrm{C}$, hot Plate, gelas ukur, gelas piala, tabung reaksi, piknometer, viskometer Oswald, pipet tetes, pH meter, tensiometer Du Nouy. Skema rangkaian alat sulfonasi dapat dilihat pada Gambar 1.

\section{Variabel Penelitian}

Pene Variabel yang digunakan dalam penelitian ini terdiri dari variabel tetap dan variabel berubah. Variabel tetap adalah volume POME $100 \mathrm{ml}$ (85,61 gr), Komposisi katalis $\mathrm{CaO} 1 \% \mathrm{w} / \mathrm{w}$ POME $(0,8561$ gr), temperatur sintesis $80^{\circ} \mathrm{C}$ dan kecepatan pengadukan $450 \mathrm{rpm}$. Variabel berubah adalah waktu sulfonasi 4, 5 dan 6 jam serta rasio mol POME : $\mathrm{Na}_{2} \mathrm{~S}_{2} \mathrm{O}_{5}$ adalah 1:0,5; $1: 1$ dan 1:1,5.

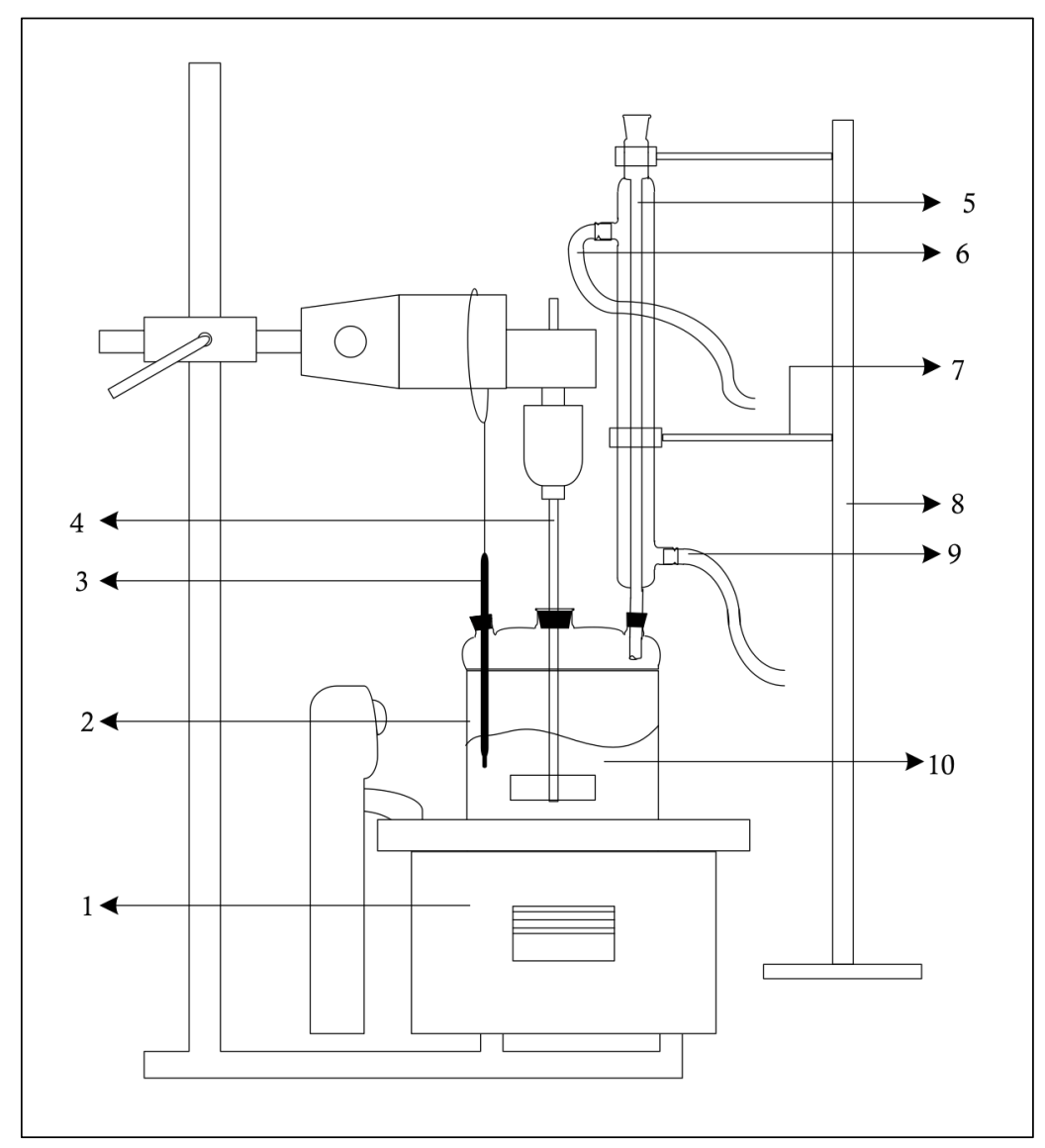

Gambar 1. Rangkaian Alat Sulfonasi 


\section{Prosedur Penelitian}

Prosedur yang akan dilakukan pada penelitian ini terdiri dari proses sulfonasi, pemurnian surfaktan MES dan Analisa Produk.

\section{Proses Sulfonasi}

Sulfonasi surfaktan MES dilakukan dengan mereaksikan POME dan natrium metabisulfit $\left(\mathrm{Na}_{2} \mathrm{~S}_{2} \mathrm{O}_{5}\right)$ dengan rasio mol 1:0,5, serta penambahan katalis $\mathrm{CaO} 1 \% \mathrm{w} / \mathrm{w}$ POME. $100 \mathrm{ml}$ POME dimasukkan kedalam reaktor leher empat, selanjutnya ditambahkan $\mathrm{Na}_{2} \mathrm{~S}_{2} \mathrm{O}_{5}$ sebanyak 58,288 gr dan katalis $\mathrm{CaO}$ 0,8561 gr. Reaksi sulfonasi berlangsung selama 4 jam pada temperatur $80^{\circ} \mathrm{C}$ dan kecepatan pengadukan $450 \mathrm{rpm}$.

Setelah proses sulfonasi selesai campuran hasil reaksi dilakukan pemisahan secara gravimetri. Tujuan dilakukan pemisahan adalah untuk memisahkan MES dengan katalis yang digunakan. MES adalah fasa cair yang berada dilapisan atas dan $\mathrm{CaO}$ berada pada fasa padat yang terdapat pada lapisan bawah. Proses sulfonasi dilakukan juga dengan perbandingan rasio mol yang berbeda yaitu $1: 1$ dan $1: 1,5$ serta variasi waktu 5 dan 6 jam.

\section{Proses Pemurnian MES}

Proses pemurnian MES dilakukan dengan pencucian menggunakan aquades. Proses pemurnian ini bertujuan untuk melarutkan garam-garam dan kotoran yang masih terkandung didalam surfaktan MES. Aquades yang digunakan dipanaskan terlebih dahulu sampai suhu $50^{\circ} \mathrm{C}$ dan ditambahkan kedalam corong pisah yang telah berisi surfaktan MES. Aquades yang telah tercampur dengan surfaktan MES dikocok terlebih dahulu dan didiamkan selama 90 menit agar garamgaram dan kotoran yang masih terkandung didalam surfaktan MES dapat terlarutkan. Proses pencucian dilakukan sebanyak 3 kali.

\section{Analisa Produk}

Produk MES dianalisa menggunakan Fourier Transform Infrared (FT-IR). FT-IR digunakan untuk mengidentifikasi gugus $\mathrm{SO}_{3}$ yang bereaksi dengan Metil Ester. Uji produk MES lainnya adalah densitas, viskositas, $\mathrm{pH}$, tegangan permukaan, dan tegangan antarmuka.

\section{HASIL DAN DISKUSI}

\section{Analisa POME}

Analisa sifat fisika POME berupa densitas, viskositas Analisa sifat fisika POME berupa densitas, viskositas dan nilai $\mathrm{pH}$. Sifat fisika POME dilihat pada Tabel 1.

\section{Proses Sulfonasi MES}

Surfaktan MES dari POME dibuat melalui reaksi sulfonasi. Jenis agen sulfonasi yang digunakan adalah Natrium Metabisulfit dan digunakan katalis Kalsium Okisida. Pembentukan produk MES berhubungan dengan waktu reaksi. Semakin lama reaksi berlangsung maka kontak antar zat semakin banyak sehingga membentuk produk yang tinggi. Interaksi antara reaktan didalam reaksi kimia dapat dilakukan dengan perataan pereaksi melalui kecepatan pengadukan ${ }^{[6]}$.

Oleh sebab itu pada penelitian ini dilakukan variasi waktu 4, 5 dan 6 jam dan kecepatan pengadukan pada proses sulfonasi adalah 450 rpm. Faktor Rasio mol reaktan juga mempengaruhi jumlah surfaktan yang terbentuk. Rasio mol yang digunakan pada penelitian ini dilakukan variasi yaitu 1:0,5 : $1: 1$ dan 1:1,5. Rasio mol merupakan perbandingan jumlah mol antara bahan baku minyak dengan agen sulfonasi yang digunakan. Rasio mol merupakan salah satu faktor yang harus dikendalikan dalam proses sulfonasi untuk menghasilkan surfaktan MES. Rasio mol reaktan sangat penting karena kelebihan reaktan menyebabkan reaksi samping berupa senyawa garam yang tidak diinginkan ${ }^{[7]}$.

Tabel 1 Sifat Fisika POME

\begin{tabular}{clc}
\hline No & Sifat Fisika & Nilai \\
\hline 1 & Berat Jenis, gr/cm & 0,8561 \\
2 & Viskositas, cp & 1,9731 \\
3 & $\mathrm{pH}$ & 3,65 \\
\hline
\end{tabular}




\section{Analisa Sifat Fisika-Kimia MES}

Pengujian dengan FT-IR bertujuan untuk mengidentifikasi senyawa dan mengetahui secara kualitatif kemungkinan berhasil atau tidaknya proses sulfonasi yang berlangsung. Pengujian dengan FT-IR akan menunjukkan apakah gugus sulfonat $\mathrm{SO}_{3}$ berhasil bereaksi dengan metil ester atau tidak. Bila terdapat gugus sulfonat dalam sampel, gugus akan terdeteksi pada spektrum bilangan gelombang puncak $1235-1070 \mathrm{~cm}^{-1[8]}$.

Dari hasil uji FT-IR, terbukti adanya gugus sulfonat dalam produk yang didapat dan menandakan bahwa surfaktan yang terbentuk adalah surfaktan MES. Analisa sampel dengan FT-IR terjadi pada daerah infra red pertengahan, yaitu pada bilangan gelombang 4000-600 $\mathrm{cm}^{-1}$. Hasil analisa sampel menunjukkan bahwa spektrum dari IR tidak hanya memperlihatkan spektrum komponen utama yaitu gugus sulfonat tetapi juga memperlihatkan komponen komponen lain yang ikut terbentuk dari spektrum IR. Daerah resapan dengan bilangan gelombang 2800$3300 \mathrm{~cm}^{-1}$ adalah gugus $\mathrm{C}-\mathrm{H}$.

Berdasarkan pada Gambar 2, adanya gugus $\mathrm{C}-\mathrm{H}$ terdapat pada bilangan gelombang $2922.78 \mathrm{~cm}^{-1}$ dan $2853,67 \mathrm{~cm}^{-1}$ yang berasal dari bahan baku POME. Pada spektrum juga terdeteksi Gugus $\mathrm{C}=\mathrm{O}$ yang berada pada resapan bilangan gelombang $1735-1750 \mathrm{~cm}^{-1}$. Gugus ester yang terdeteksi berasal dari POME. Pada Gambar 2 terlihat bahwa gugus $\mathrm{C}=\mathrm{O}$ terbentuk pada resapan bilangan gelombang $1742,42 \mathrm{~cm}^{-1}$. Sedangkan gugus sulfonat hasil analisa FT-IR pada Gambar 2 terjadi pada bilangan gelombang sekitar $1169,78 \mathrm{~cm}^{-1}$. Terdeteksinya gugus sulfonat maka disimpulkan bahwa sulfonasi POME dengan agen sulfonasi $\mathrm{Na}_{2} \mathrm{~S}_{2} \mathrm{O}_{5}$ berhasil membentuk surfaktan MES. Semakin murni suatu produk maka semakin tajam pola spektra yang terbentuk.

\section{Hasil analisa densitas, viskositas, $\mathrm{pH}$, tegangan permukaan, dan tegangan antarmuka surfaktan MES}

Pada Tabel 1 ditampilkan sifat fisika POME yang diperoleh dari PT. Cemerlang Eka Perkasa Dumai, Provinsi Riau. POME yang digunakan untuk sintesis surfaktan MES memiliki nilai densitas $0,8561 \mathrm{gr} / \mathrm{cm}^{3}$, Viskositas 1,9731 cp, dan nilai $\mathrm{pH}$ 3,65. Selanjutnya POME digunakan sebagai bahan baku proses sintesis surfaktan MES dengan proses sulfonasi.

Pada penelitian ini yield yang dihasilkan dari proses sulfonasi yaitu sebesar $87 \%$. Yield Produk surfaktan MES yang dihasilkan cenderung meningkat dengan penggunaan katalis $\mathrm{CaO} 1 \%$. Hal ini disebabkan karena katalis $\mathrm{CaO}$ yang digunakan akan meningkatkan jumlah tumbukan antara POME dengan $\mathrm{Na}_{2} \mathrm{~S}_{2} \mathrm{O}_{5}$. Peningkatan jumlah tumbukkan dapat diduga mempercepat reaksi sulfonasi dengan menurunkan energi aktivasi sehingga semakin banyaknya $\mathrm{Na}_{2} \mathrm{~S}_{2} \mathrm{O}_{5}$ yang terikat dengan POME membentuk surfaktan MES

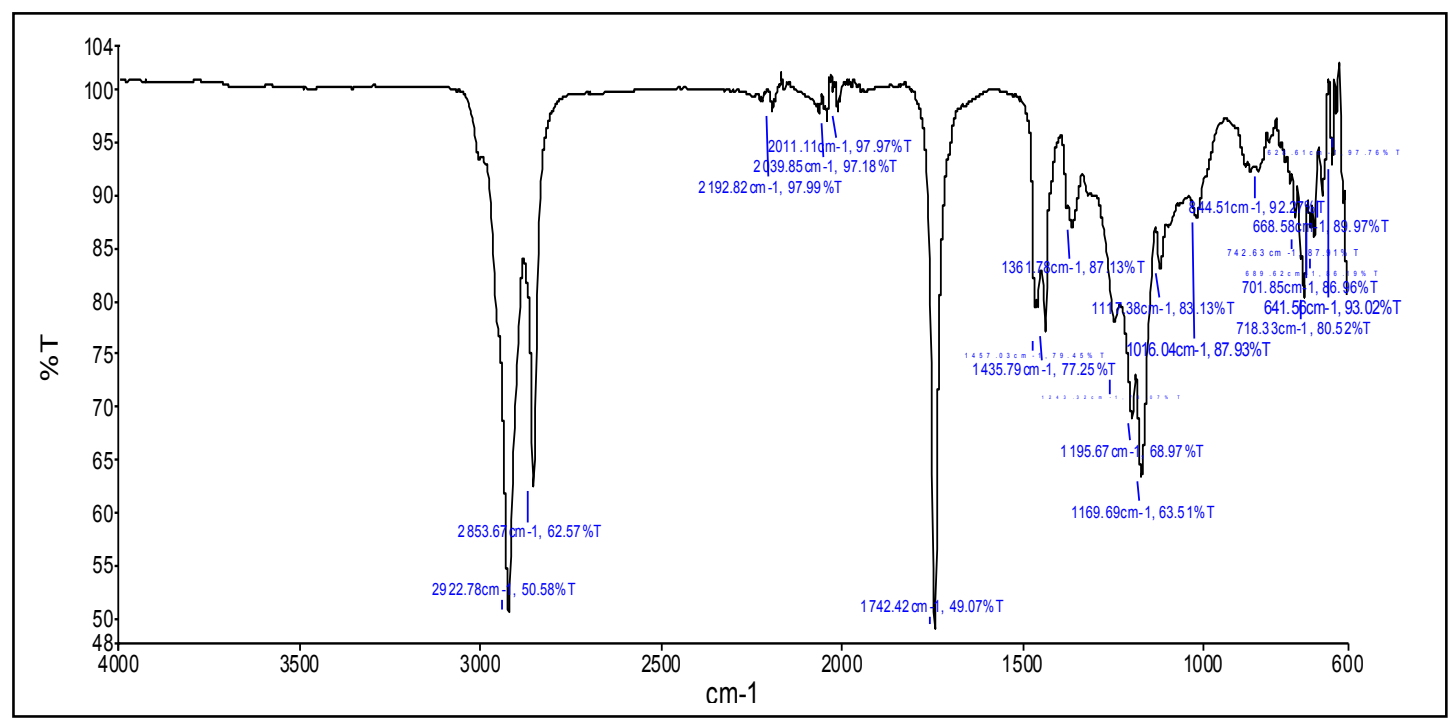

Gambar 2. Hasil uji FT-IR sampel MES 
Selanjutnya dilakukan analisa nilai densitas, viskositas, dan nilai $\mathrm{pH}$ pada produk surfaktan MES. Nilai densitas MES yang dihasilkan pada penelitian mengalami peningkatan dari nilai densitas bahan baku POME, yaitu dari $0,8561 \mathrm{~g} / \mathrm{cm}^{3}$ menjadi $0,8954 \mathrm{~g} / \mathrm{cm}^{3}$. Nilai viskositas MES yang dihasilkan pada penelitian juga mengalami peningkatan dari viskositas bahan baku POME yaitu dari 1,9731 cP menjadi 2,1329 cP. Hubungan antara rasio mol dan waktu reaksi terhadap densitas dan viskositas dapat dilihat pada Gambar 3 dan 4.

Bertambahnya nilai densitas dan viskositas merupakan indikator bahwa selama proses sulfonasi terjadi konversi POME menjadi surfaktan MES. Meningkatnya nilai densitas dan viskositas dipengaruhi oleh ukuran molekul dan gaya antarmolekul. Terikatnya gugus sulfonat $\mathrm{SO}_{3}$ pada POME menjadikan MES cenderung memiliki ukuran molekul yang lebih besar sehingga memiliki densitas dan viskositas yang lebih tinggi dibandingkan bahan bakunya. Nilai densitas dan viskositas MES meningkat seiring dengan peningkatan waktu reaksi dan rasio mol reaktan antara POME dan $\mathrm{Na}_{2} \mathrm{~S}_{2} \mathrm{O}_{5}$ yaitu pada rasio mol 1:1,5 dan waktu sulfonasi selama 6 jam.

Selanjutnya dilakukan analisa nilai $\mathrm{pH}$ dengan tujuan untuk mengetahui derajat keasaman MES yang dihasilkan pada proses sulfonasi. Hasil analisa pH MES pada berbagai kondisi operasi proses menunjukan kisaran nilai antara 2,03-2,48.

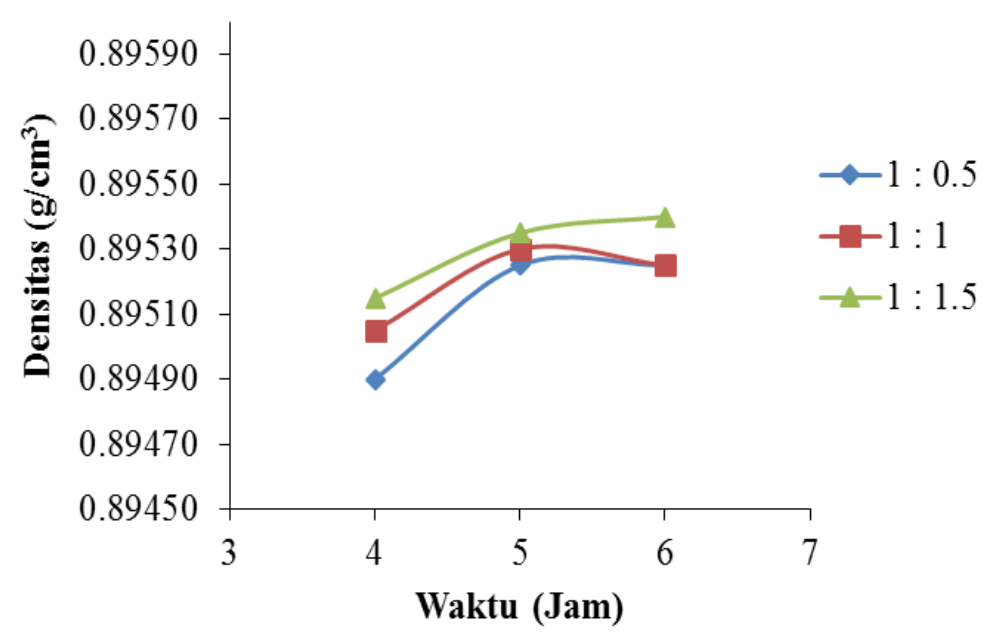

Gambar 3. Grafik Hubungan antara Rasio Mol dan Waktu Reaksi terhadap Densitas

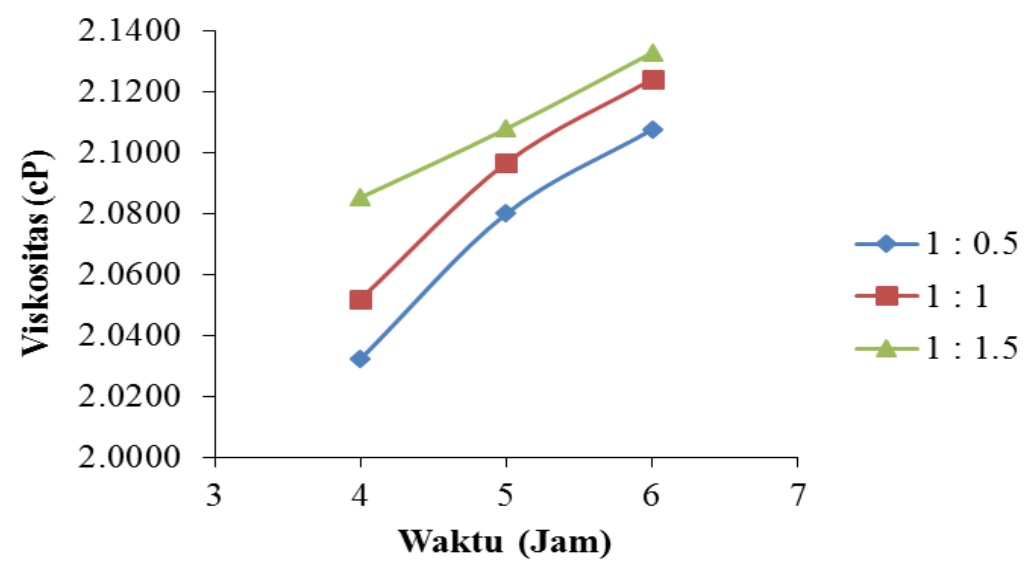

Gambar 4. Grafik Hubungan antara Rasio Mol dan Waktu Reaksi terhadap Viskositas 
Pada penelitian ini nilai $\mathrm{pH}$ MES mengalami penurunan seiring dengan semakin besarnya rasio mol dan semakin lamanya proses sulfonasi. Penurunan $\mathrm{pH}$ ini diduga karena semakin banyaknya $\mathrm{Na}_{2} \mathrm{~S}_{2} \mathrm{O}_{5}$ yang terikat pada POME seiring dengan semakin lamanya waktu sulfonasi dan semakin besarnya rasio mol reaktan. $\mathrm{Na}_{2} \mathrm{~S}_{2} \mathrm{O}_{5}$ yang digunakan sebagai pereaksi merupakan kelompok garam asam yang bersifat asam lemah.

pH MES yang dihasilkan pada penelitian lebih rendah jika dibandingkan dengan $\mathrm{pH}$ MES komersi ${ }^{[9]}$ yang dihasilkan dari chemithon adalah 5,3. Hal ini disebabkan pada proses sintesis MES yang dilakukan chemiton, adanya proses tambahan yang dapat meningkatkan nilai pH MES yaitu proses netralisai dengan penambahan Sodium Hidroxide $(\mathrm{NaOH})$. Pengaruh penambahan proses netralisasi dapat dilihat dari penelitian yang dilakukan Adiandri ${ }^{[10]}$, dimana $\mathrm{pH}$ MES sebelum dilakukan proses netralisasi adalah 3,95 - 4,93 dan setelah dilakukan proses netralisasi $\mathrm{pH}$ meningkat menjadi 6,92 7,67 . Hubungan antara rasio mol dan waktu reaksi terhadap $\mathrm{pH}$ dapat dilihat pada Gambar 5.

Surfaktan MES yang dihasilkan pada penelitian ini mampu menurunkan tegangan permukaan air dari $71,4 \mathrm{mN} / \mathrm{m}$ menjadi $37.55 \mathrm{mN} / \mathrm{m}-38.8 \mathrm{mN} / \mathrm{m}$, dengan nilai penurunan tegangan permukaan antara 33.85
$\mathrm{mN} / \mathrm{m}-32.60 \mathrm{mN} / \mathrm{m}$. Hasil analisa menunjukann bahwa surfakatan yang dihasilkan cukup efektif untuk menurunkan tegangan permukaan air. Surfaktan MES yang dihasilkan dalam penelitian ini juga mampu menurunkan tegangan antarmuka antara air sebagai fasa polar dan xilen sebagai fasa non polar. Surfaktan MES yang dihasilkan pada penelitian ini mampu menurunkan tegangan antarmuka air dari $35,8 \mathrm{mN} / \mathrm{m}$ menjadi $4,87 \mathrm{mN} / \mathrm{m}-5,35$ $\mathrm{mN} / \mathrm{m}$, dengan nilai penurunan tegangan permukaan antara $30,45 \mathrm{mN} / \mathrm{m}-30,94$ $\mathrm{mN} / \mathrm{m}$.

Nilai tegangan permukaan air yang dihasilkan pada penelitian ini lebih rendah jika dibandingkan dengan nilai tegangan permukaan air yang dihasilkan Pore ${ }^{[11]}$ yang mampu menurunkan tegangan permukaan air dari $72 \mathrm{mN} / \mathrm{m}$ menjadi $39 \mathrm{mN} / \mathrm{m}$ - 40,2 $\mathrm{mN} / \mathrm{m}$, dengan nilai penurunan tegangan permukaan antara $33 \mathrm{mN} / \mathrm{m}-31,8 \mathrm{mN} / \mathrm{m}$. Nilai tegangan permukaan yang rendah akan menghasilkan nilai penurunan tegangan permukaan yang tinggi. Sehingga surfaktan MES yang dihasilkan sudah memenuhi standar surfaktan komersil.

Hubungan antara rasio mol dan waktu reaksi terhadap nilai tegangan permukaan dan tegangan antarmuka dapat dilihat pada Gambar 6 dan 7.

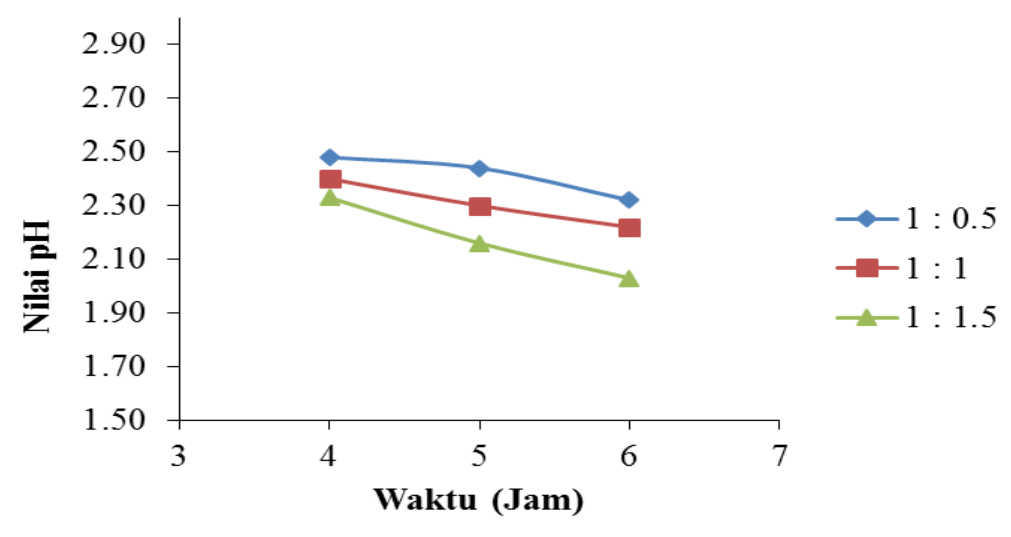

Gambar 5. Grafik Hubungan antara Rasio Mol dan Waktu Reaksi terhadap pH 


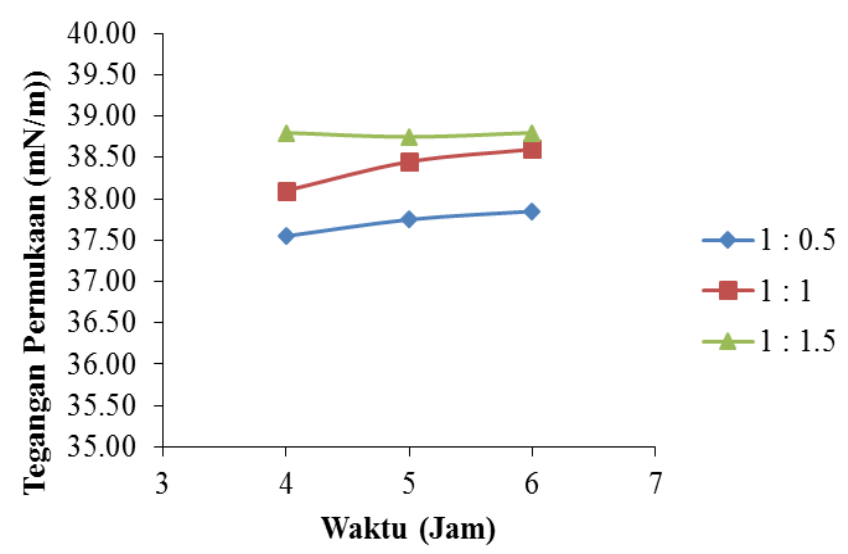

Gambar 6. Grafik Hubungan antara Rasio Mol dan Waktu Reaksi terhadap Nilai Tegangan Permukaan

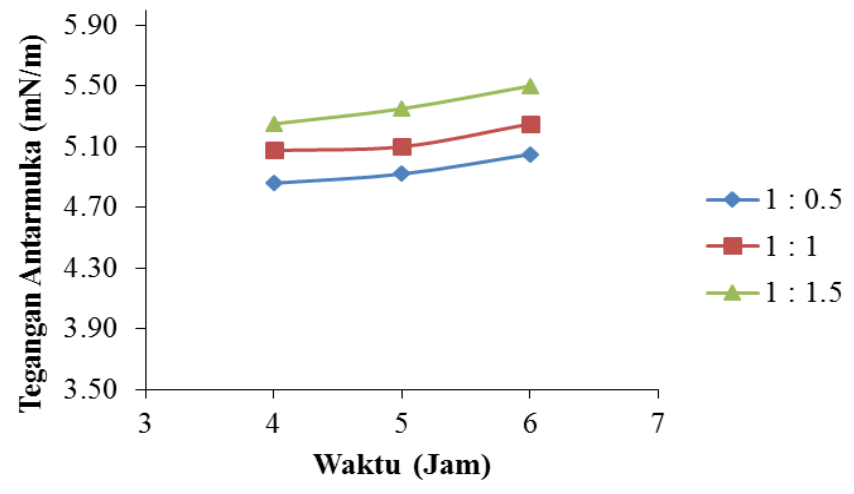

Gambar 7. Grafik Hubungan antara Rasio Mol dan Waktu Reaksi terhadap Tegangan Antarmuka antara air-xilen

\section{KESIMPULAN}

Berdasarkan kriteria tegangan antarmuka dan tegangan permukaan, maka dapat disimpulkan kondisi proses sulfonasi terbaik dari rasio mol reaktan dan lama reaksi adalah 1:1,5 selama 6 jam. Karakteristik surfaktan yang dihasilkan pada penelitian ini mampu menurunkan tegangan permukaan air dan tegangan antarmuka xilen-air sebesar 33,85 $\mathrm{mN} / \mathrm{m}$ dan $5,5 \mathrm{mN} / \mathrm{m}, \mathrm{pH} \mathrm{2,48}$, Densitas $0,8954 \mathrm{~g} / \mathrm{cm}^{3}$, dan Viskositas $2,13 \mathrm{cP}$.

\section{DAFTAR PUSTAKA}

1. Hapsari, M. 2003. Kajian pengaruh suhu dan kecepatan pengadukan pada proses produksi surfaktan dari metil ester minyak inti sawit dengan metode sulfonasi. Thesis. IPB: Bogor

2. Chasani, M., V.H. Nursalim., S. Widyaningsih., I.N. Budiasih., dan M.A Kurniawan. 2014. Sintesis, Pemurnian dan Karakterisasi Metil Ester Sulfonat (MES) sebagai Bahan Inti Deterjen dari Minyak Biji Nyamplung. Molekul.Vol.9: 63-72

3. Sulastri, Y. 2010. Sintesis Methyl Ester Sulfonic Acid (MESA) dari Crude Palm Oil (CPO) menggunakan Single Tube Falling Film reaktor. Thesis. IPB: Bogor

4. Hidayati, S. 2009. Pengaruh Rasio Mol, Suhu dan Lama Reaksi terhadap Tegangan Permukaan dan Stabilitas Emulsi Metil Ester Sulfonat Dari CPO. Jurnal Teknologi Industri dan Hasil Pertanian. Vol.14:38-44 
5. Helianty, S dan Zulfansyah. 2011. Pembuatan Ester metilsulfonat dari ester metil Palm Stearin. Jurnal Teknobiologi. Vol.II: $37-39$

6. Ebbing, D.D dan M.S Wringhton. 1990. General Chemistry. 3 rd Edition. Wilmington-USA: Houghton Mifflin Company

7. Foster, N.C. 1996. Sulfonation and Sulfation Processes. In: Spitz, L. (Ed). Soap and Detergents: A Theoretical and Practical Review. AOCS Press, Champaign, Illinois

8. American Society for Testing and Material (ASTM). 2001. Annual Book of ASTM Standards: Soap and Other Detergent, Polishes, Leather, Resilient Floor Covering. Baltimore: ASTM. PP 915-919

9. Sheats, W.B dan B.W MacArthur. 2002. Methyl Ester Sulphonate Products: The Chemithon Corporation, USA

10. Adiandri, R.S. 2006. Kajian Pengaruh Konsentrasi Metanol dan Lama Reaksi pada proses Pemurnian Metil Ester Sulfonat terhadap Karakteristik Detergen Bubuk. Thesis. IPB: Bogor

11. Pore, J. 1993. Oils and Fat Manual. Intercept Ltd, Andover, Uk, Paris :New York 